University of Nebraska - Lincoln

DigitalCommons@University of Nebraska - Lincoln

Agronomy \& Horticulture -- Faculty Publications

Agronomy and Horticulture Department

2013

\title{
Arbuscular mycorrhizal fungi differ in their ability to regulate the expression of phosphate transporters in maize (Zea mays L.)
}

Hui Tian

Northwest A\&F University

Rhae A. Drijber

University of Nebraska-Lincoln, rdrijber1@unl.edu

Xiaolin Li

China Agricultural University

Daniel N. Miller

USDA-ARS, dan.miller@ars.usda.gov

Brian J. Wienhold

USDA-ARS, Brian.Wienhold@ars.usda.gov

Follow this and additional works at: https://digitalcommons.unl.edu/agronomyfacpub

Part of the Agricultural Science Commons, Agriculture Commons, Agronomy and Crop Sciences Commons, Botany Commons, Horticulture Commons, Other Plant Sciences Commons, and the Plant Biology Commons

Tian, Hui; Drijber, Rhae A.; Li, Xiaolin; Miller, Daniel N.; and Wienhold, Brian J., "Arbuscular mycorrhizal fungi differ in their ability to regulate the expression of phosphate transporters in maize (Zea mays L.)" (2013). Agronomy \& Horticulture -- Faculty Publications. 682.

https://digitalcommons.unl.edu/agronomyfacpub/682

This Article is brought to you for free and open access by the Agronomy and Horticulture Department at DigitalCommons@University of Nebraska - Lincoln. It has been accepted for inclusion in Agronomy \& Horticulture -Faculty Publications by an authorized administrator of DigitalCommons@University of Nebraska - Lincoln. 


\title{
Arbuscular mycorrhizal fungi differ in their ability to regulate the expression of phosphate transporters in maize (Zea mays L.)
}

\author{
Hui Tian • Rhae A. Drijber • Xiaolin Li • \\ Daniel N. Miller • Brian J. Wienhold
}

This article is a U.S. government work, and is not subject to copyright in the United States.

Received: 12 November 2012 / Accepted: 18 February 2013 / Published online: 7 March 2013

(C) Springer-Verlag Berlin Heidelberg 2013

\begin{abstract}
Previous studies have found that some phosphate (Pi) starvation inducible transporter genes are downregulated and arbuscular mycorrhizal (AM) inducible Pi transporter genes are upregulated in maize roots associated with the fungus Glomus intraradices. However, little is known about the functional diversity of different AM fungal species in influencing the expression of Pi transporters in maize roots. Here, we studied the expression of two Pi transporter genes ZEAma:Pht1;3 (Pi starvation inducible) and ZEAma:Pht1;6 (AM inducible) in maize root colonized by different $A M$ fungal inoculants. Non-mycorrhizal maize, maize colonized by Glomus deserticola (CA113), Glomus intraradices (IA506), Glomus mosseae (CA201), Gigaspora gigantea (MN922A) and the co-inoculation of all four species were established. The expression patterns of the two genes were quantified using real-time, reverse transcription polymerase chain reaction. The expression level of ZEAma:Pht1;6 was 26-135 times higher in AM plants than in non-mycorrhizal maize roots, whereas the expression level of ZEAma:Pht1;3
\end{abstract}

H. Tian

College of Natural Resources and Environment, Northwest A\&F

University, Yangling, Shaanxi 712100, People's Republic of China

\section{R. A. Drijber $(\bowtie)$}

Department of Agronomy and Horticulture,

University of Nebraska-Lincoln, 316 Keim Hall,

Lincoln, NE 68503-0915, USA

e-mail: rdrijber1@unl.edu

\section{X. $\mathrm{Li}$}

Department of Environmental Science and Engineering, China Agricultural University, 2 Yuanmingyuan West Road,

Beijing 100094, People's Republic of China

D. N. Miller · B. J. Wienhold

USDA-ARS, Lincoln, NE 68583-0915, USA was five to 44 times lower in AM plants than in nonmycorrhizal plants. Expression of the two genes differed with inoculation treatment, and increasing the diversity of AM fungi in maize roots led to greater expression of ZEAma: Pht1;6 as well as Pi uptake in shoots. The expression of ZEAma:Pht1;6 was significantly positively correlated with AM colonization rate, concentration of AM biomarkers in maize roots, Pi uptake and dry weight of shoot, but negatively correlated with the expression of ZEAma:Pht1;3. Addition of Pi fertilizer at a low concentration significantly increased the expression of ZEAma:Pht1;6 but had no effect on the expression of ZEAma:Pht1;3.

Keywords Arbuscular mycorrhizal fungi · Maize · Pi transporter gene $\cdot$ Phosphorus $\cdot$ Real-time RT-PCR . Fatty acid biomarker

\section{Introduction}

Arbuscular mycorrhizal (AM) fungi are known to form mutualistic associations with the roots of the majority of terrestrial plant species, and stimulate host plant growth mainly by enhancing the uptake of phosphorus (Smith and Read 2008). The symbioses are potentially able to acquire phosphorus via two pathways: directly via root epidermal cells and root hairs, and via the AM fungi (Smith et al. 2003). Phosphate (Pi) transporters play important roles in $\mathrm{Pi}$ transfer for both pathways (Benedetto et al. 2005; Javot et al. 2007). It is reported that there are three types of genes encoding Pht 1 transporters involved in $\mathrm{Pi}$ uptake regulation by $\mathrm{AM}$ plant associations: AM fungal $\mathrm{Pi}$ transporter genes, plant $\mathrm{Pi}$ transporter genes, and AM-inducible plant Pi transporter genes (Javot et al. 2007). 
The plant Pi transporters and AM-inducible Pi transporters are mainly expressed in roots, especially in rhizodermal cells (Bucher 2007); however, the AMinducible Pi transporters are predominantly or exclusively expressed in root cells containing arbuscules when roots are colonized by AM fungi (Javot et al. 2007). It is believed that the AM-inducible plant Pi transporters are involved in the acquisition of Pi released by the AM fungus at the symbiotic interface and can be used as markers for the symbiotic Pi uptake pathway (Grace et al. 2009). A limited number of AM-inducible plant Pi transporters have been identified in Medicago truncatula (Harrison et al. 2002), rice (Paszkowski et al. 2002), potato (Nagy et al. 2005), wheat (Glassop et al. 2005), and tomato (Nagy et al. 2005). In maize, at least eight Pi transporters have been cloned up to now, they are ZEAma;Pht1;1-6 (AY974041-AY974046), ZmPT3 (AY639021), and ZmPT4 (AY639022) (Nagy et al. 2006; Wright et al. 2005). The gene ZEAma;Pht1;6 has been identified as an AM-inducible Pi transporter in maize (Glassop et al. 2005). This gene was strongly expressed in mycorrhizal roots, with limited expression in nonmycorrhizal plants (Glassop et al. 2005) and older leaves under low Pi conditions (Nagy et al. 2006). Although ZEAma;Pht1;6 may not be a strict AM specific-induced Pi transporter (Javot et al. 2007), evidence suggests that this gene is involved in Pi uptake via the mycorrhizal uptake pathway (Nagy et al. 2006).

Few studies have focused on the expression of Pi transporters in maize root colonized by AM fungi (Glassop et al. 2005; Nagy et al. 2006; Wright et al. 2005). These studies concluded that when maize roots were colonized by AM fungi, the gene ZEAma;Pht1;6 had increased expression while the expression of several other Pi starvationinducible Pi transporters, such as, ZEAma;Pht1;1, decreased. These studies mainly used one AM species (Glomus intraradices); thus, it is unclear how different AM species induce expression of Pi transporters in maize roots. It has been reported that different AM species or isolates have varying influence on the expression of $\mathrm{Pi}$ transporters in plant species such as M. truncatula and tomato (Burleigh et al. 2002; Poulsen et al. 2005). Furthermore, little is known about the relationship between the expression of $\mathrm{Pi}$ transporters in maize roots colonized by AM fungi and the growth or Pi uptake of maize. It is wellknown that AM species show functional diversity in plant growth or Pi uptake; however, the molecular mechanisms underlying functional diversity are still not clear for many AM associations (Burleigh et al. 2002).

Therefore, the aim of the present study was to determine whether the expression patterns of Pi transporters using, reverse transcription polymerase chain reaction (Real-time RT-PCR) in maize roots varies among AM inoculants and whether this translates to functional diversity in Pi uptake.

\section{Methods and materials}

Production of AM fungal inoculum

Four AM fungal species, Glomus deserticola (CA113), Glomus intraradices (IA506), Glomus mosseae (CA201), and Gigaspora gigantea (MN922A), were ordered from the International Culture Collection of Arbuscular Mycorrhizal Fungi (http://invam.caf.wvu.edu) and were propagated on maize (Zea mays L.) in pasteurized soil-sand mix (containing $25 \%$ soil and $75 \%$ quartz sand). Plants were cultured in the greenhouse for 4 months under $28^{\circ} \mathrm{C}$ in the daytime and $25{ }^{\circ} \mathrm{C}$ in the night. The root colonization by AM fungi was checked during the culture, and the presence of spores was confirmed by sieving.

Plant growth conditions

Maize plants (local, but unknown commercial hybrid) were cultured in 3-L cylinder pots filled with $3-\mathrm{L}$ pasteurized soil-quartz sand mixture $(1: 3)(v / v)$. Treatments of nonmycorrhizal, single-inoculations of $G$. deserticola, $G$. intraradices, G. mosseae, Gigaspora gigantea, and the coinoculation of all four AM species were set up and planted to maize. To inoculate the pots, $100 \mathrm{~g}$ of each AM fungal inoculum (for the mixture inoculation, $25 \mathrm{~g}$ each of the four $\mathrm{AM}$ species) was mixed into a $2.5-\mathrm{kg}$ mixture. The AM fungal inoculum contains AM spores, AM extra-radical hyphae as well as root fragments. For the nonmycorrhizal treatment, $100 \mathrm{~g}$ of pasteurized soil-quartz sand mixture (1:3) was mixed into the quartz sand mixture instead of AM fungal inoculum. There were eight replicates for each AM treatment. Two pregerminated maize seeds were sown in each pot on November 2, 2009. After the seedlings emerged, the plants were thinned to one per pot, and the pots were placed in a greenhouse with $16 / 8$-h light/dark cycle at $28 / 25^{\circ} \mathrm{C}$. Four of the eight replicates for each AM treatment were watered with $400 \mathrm{~mL}$ of Hoagland nutrient solution with $\mathrm{Pi}(1 \mathrm{mM}$ $\left.\mathrm{KH}_{2} \mathrm{PO}_{4}\right)(+\mathrm{Pi}$ treatment) and without $\mathrm{Pi}(-\mathrm{Pi}$ treatment) in each pot, respectively. The pots were watered with Hoagland nutrient solution once a week from November 8 for 9 weeks. Each pot received $435.4 \mathrm{mg}$ of $\mathrm{KH}_{2} \mathrm{PO}_{4}$ in total for the $+\mathrm{Pi}$ treatment.

\section{Harvest}

Plants were harvested on 5 January 2010. Shoots were cut, oven-dried at $75{ }^{\circ} \mathrm{C}$ for $72 \mathrm{~h}$, and then weighed. Dry shoots were crushed using a blender into a powder to determine $\mathrm{Pi}$ content using the method of van Aarle et al. (2002). The roots were washed with distilled water and divided into three parts: one part was stored in liquid nitrogen for RNA extraction; one 
part was stored at $-20{ }^{\circ} \mathrm{C}$ for the measurement of percent root colonization by AMF; and the remaining part was freeze dried at $-50{ }^{\circ} \mathrm{C}$ for $48 \mathrm{~h}$ then frozen at $-20^{\circ} \mathrm{C}$ until measurement of AM fungal fatty acid biomarkers.

AM colonization and concentration of AM biomarkers in maize roots

Roots were cut into about 1-cm long segments and stained with $0.05 \%(w / v)$ Trypan blue (Phillips and Hayman 1970), and the percent root colonization by AM fungi was calculated as described by Trouvelot et al. (1986). To quantify AM fatty acid biomarkers in maize roots, freeze-dried maize roots were roller-milled for $12 \mathrm{~h}$ at room temperature. Fatty acids were extracted from 30- to 50-mg roller-milled roots using the method of Grigera et al. (2007a). The fatty acids C16:1cis 11 and C18:1cis11 were selected as biomarkers for the AM fungi (Grigera et al. 2007a), although C16:1cis11 has also been reported in a few bacteria (Zelles 1999) and some zygomycetous fungi (Amano et al. 1992), and C18:1cis11 is common to several gram-negative bacteria (Zelles 1999). The extraction procedure we used on freezedried and ground roots recovers ester-linked fatty acids from neutral, glycol- and phospho-lipid pools within the intraradical hyphae, vesicles, spores, and arbuscules in maize roots as well as extra-radical structures remaining on root surfaces (Grigera et al. 2007b).

\section{Real-time RT-PCR analysis of Pi transporter genes}

Total RNA was extracted from about $80-\mathrm{mg}$ maize roots using the RNeasy Mini Kit (QIAGEN). Approximately $1 \mu \mathrm{g}$ of the total RNA was used as a template for first-strand cDNA synthesis using QuantiTect Reverse Transcription Kit (QIAGEN) according to the manufacture's instructions. Random primers supplied by the kit were used during the reverse transcription reaction. The cDNA was stored at $-20{ }^{\circ} \mathrm{C}$ until analysis.

Before real-time RT-PCR was conducted, gene-specific primers for AM-inducible Pi transporter ZEAma:Pht1;6 (forward: 5'-ACATAAACGCCCTCAAGGAG-3' and reverse: 5'-GACGGTGACCCAGTAGCC-3'), which produced a 92bp-long fragment, were designed using Primer Premier (version 5.0) software (Palo Alto, CA). For other Pi transporters, the Pi starvation-inducible Pi transporter gene ZEAma:Pht1;3 (Nagy et al. 2006) was selected. Quantification of additional $\mathrm{Pi}$ transporters is needed, but the design of gene-specific primers for real-time PCR is problematic due to a high degree of similarity (Nagy et al. 2006). The specific primers for ZEAma:Pht 1;3 was forward: 5'-GCATGCATGCATG CAAATG-3' and reverse: 5'- CGAAAACAACAGTA CTTGATTGATC-3') (Nagy et al. 2006), and a 354-bp-long fragment was amplified. Primers were tested by PCR experiments on genomic DNA of AM fungi to exclude cross-hybridization with fungal templates (data not shown). To quantify the expression of Pi transporter genes, standard curves were made for both ZEAma:Pht1;6 and ZEAma: Pht1;3. For the gene ZEAma:Pht1;6, the PCR thermal program consisted of an initial denaturation at $94^{\circ} \mathrm{C}$ for $1 \mathrm{~min}$, followed by 35 cycles of denaturation at $94{ }^{\circ} \mathrm{C}$ for $1 \mathrm{~min}$, annealing at $54{ }^{\circ} \mathrm{C}$ for $1 \mathrm{~min}$, extension at $72{ }^{\circ} \mathrm{C}$ for $1 \mathrm{~min}$, and one cycle of $72^{\circ} \mathrm{C}$ for $10 \mathrm{~min}$. For ZEAma:Pht1;3, the PCR program was one cycle of $94{ }^{\circ} \mathrm{C}$ for $5 \mathrm{~min}, 35$ cycles of $94{ }^{\circ} \mathrm{C}$ for $30 \mathrm{~s}, 58^{\circ} \mathrm{C}$ for $30 \mathrm{~s}, 72^{\circ} \mathrm{C}$ for $1 \mathrm{~min}$ and one cycle of $72{ }^{\circ} \mathrm{C}$ for $10 \mathrm{~min}$. The PCR products were purified and cloned into TOPO 2.1 vector using TOPO TA Cloning kit (Invitrogen) following the manufacturer's instructions. Plasmid DNA was purified from positive clones using the Wizard Plus Minipreps DNA Purification System (Promega). The occurrence of target genes in the plasmid DNA was verified by sequencing. The concentration of purified plasmid DNA was determined by spectrophotometry (Model: Biomate 3 ) at $260 \mathrm{~nm}$, and the molecular weight of DNA was calculated using the formula $\mathrm{NC}=(\mathrm{K} \times \mathrm{Na}) /(660 \times \mathrm{L})$, where $L$ is the average DNA fragment length for each gene, $K$ is the DNA concentration determined from its absorbance at $260 \mathrm{~nm}, 660$ is the molecular mass of DNA in Da per base pair, and Na is Avogadro's constant $\left(6.023 \times 10^{23}\right)$. The plasmid DNA was then serially diluted with sterile water to obtain $10^{9}-10^{2}$ copies per microliter.

One microliter of first strand cDNA or standard plasmid DNA mixed with QuantiFast SYBR Green Master Mix (QIAGEN) following the manufacture's instructions was used for real-time RT-PCR. Real-time RT-PCR was conducted using the iCycler iQ (Bio-Rad), and the thermal cycling consisted of an initial denaturation at $95{ }^{\circ} \mathrm{C}$ for $5 \mathrm{~min}$, followed by 45 cycles of denaturation at $95{ }^{\circ} \mathrm{C}$ for $10 \mathrm{~s}$, annealing/extension at $60{ }^{\circ} \mathrm{C}$ for $30 \mathrm{~s}$ (for the gene $Z E A m a$ : Pht ; 6) $\left(60^{\circ} \mathrm{C}\right.$ for $60 \mathrm{~s}$ for ZEAma:Pht $\left.; 3\right)$, and $80^{\circ} \mathrm{C}$ for $15 \mathrm{~s}$. The fluorescence signal data were detected at the third step of the cycle to eliminate the signal of possible primer dimmers. Each reaction was performed in triplicate, and the average threshold cycle value was calculated for each sample. There were four biological replicates for each treatment. To calibrate gene expression data, a maize housekeeping gene, $\gamma$-tubulin, was used as a control (Ding et al. 2009). This gene showed a stable expression throughout the course of our experiment, although re-arrangement of the cytoskeleton may occur during symbiosis development (Genre and Bonfante 1998). The primers for this gene, which can amplify a 131-bp fragment, was: forward: 5'-GTCCTGTGCCACTCTATTGC-3' and reverse: 5'-CTTGTTTCCACCTGATTTGG-3'. The standard curve for the $\gamma$-tubulin gene followed the same protocol as the Pi transporter genes, with a thermal program of one cycle of $94{ }^{\circ} \mathrm{C}$ for $4 \mathrm{~min}, 35$ cycles of $94^{\circ} \mathrm{C}$ for $1 \mathrm{~min}, 52^{\circ} \mathrm{C}$ for $1 \mathrm{~min}$, $72{ }^{\circ} \mathrm{C}$ for $1 \mathrm{~min}$, and one cycle of $72{ }^{\circ} \mathrm{C}$ for $10 \mathrm{~min}$. Real-time 
RT-PCR was performed under the same conditions as the Pi transporter gene ZEAma:Pht1;6.

\section{Statistics}

The influence of AM inoculation and Pi treatment on AM colonization, concentration of AM biomarkers in maize root, maize growth parameters, and expression of Pi transporters were analyzed by factorial ANOVA, and the means compared by least significant difference at the 0.05 level using SAS 8.2 (SAS Institute 1999). Pearson correlation coefficients were used to determine relationships among AM colonization, AM biomarkers, maize growth parameters, and Pi transporter expression parameters.

\section{Results}

AM colonization and concentration of AM biomarkers in maize roots

AM fungi colonized maize roots in all five inoculated treatments but not in the non-mycorrhizal control. Both AM inoculation $(P<0.0001)$ and $\mathrm{Pi}$ treatment $(P<0.05)$ influenced percent root colonized by AM fungi (Table 1). The percent root colonized by Gigaspora gigantea was significantly lower than the other four AM inoculations, which were not significantly different from one another in either Pi treatment (Table 1). Overall, the addition of Pi significantly decreased percent root colonized by AM fungi.

The influence of AM inoculation $(P<0.001)$ and the interaction of AM inoculation and Pi treatment $(P<0.01)$ on AM fatty acid biomarkers (C16:1cis11 and C18:1cis11) were significant (Table 1). The highest concentration of the AM biomarker C16:1cis11 was found in roots colonized by $G$. intraradices, and the concentration of this fatty acid was also significantly higher in roots inoculated with the AM mix than with $G$. deserticola, G. mosseae or Gigaspora gigantea in both Pi treatments (Table 1). This fatty acid biomarker was not detected in non-mycorrhizal roots. The AM biomarker $\mathrm{C} 18: 1$ cis11 was highest in roots colonized by $G$. deserticola and lowest in non-mycorrhizal roots in both Pi treatments. The concentration of C18:1cis 11 was significantly lower in roots colonized by Gigaspora gigantea than by $G$. mosseae or the AM mix (Table 1). The addition of Pi did not significantly influence the concentration of AM biomarkers in maize roots $(P>0.05)$.

Plant shoot dry weight and Pi uptake

Different AM species showed functional diversity in either shoot dry weight or Pi uptake. AM inoculation $(P<0.0001)$, Pi treatment $(P<0.0001)$ as well as their interaction $(P<0.0001)$

Table 1 Influence of different AM and phosphate (Pi) treatments to maize on AM colonization, shoot dry weight, Pi uptake, and AM fungal fatty acid biomarkers (C16:1cis11, C18:1 cis11)

\begin{tabular}{|c|c|c|c|c|c|c|}
\hline Pi treatment & AM inoculation & $\begin{array}{l}\text { Colonization } \\
\text { rate }(\%)\end{array}$ & $\begin{array}{l}\text { Shoot dry weight } \\
\text { (g per plant) }\end{array}$ & $\begin{array}{l}\text { Pi uptake } \\
\text { (mg per plant) }\end{array}$ & $\begin{array}{l}\mathrm{C} 16: 1 \text { cis } 11 \\
\left(\mathrm{nmolmg}^{-1}\right)\end{array}$ & $\begin{array}{l}\text { C18:1cis } 11 \\
\left(\mathrm{nmolmg}^{-1}\right)\end{array}$ \\
\hline \multirow[t]{6}{*}{$-\mathrm{Pi}$} & Non-mycorrhizal & 0 & $6.9 \pm 0.8 \mathrm{~d}$ & $6.55 \pm 1.4 \mathrm{~d}$ & 0 & $0.35 \pm 0.2 \mathrm{~d}$ \\
\hline & Glomus deserticola & $72.4 \pm 5.8 \mathrm{a}$ & $16.5 \pm 1.1 \mathrm{c}$ & $37.9 \pm 2.1 \mathrm{bc}$ & $0.7 \pm 0.06 \mathrm{c}$ & $3.5 \pm 0.29 \mathrm{a}$ \\
\hline & Glomus intraradices & $84.6 \pm 1.9 \mathrm{a}$ & $21.7 \pm 0.5 \mathrm{a}$ & $35.8 \pm 2.1 \mathrm{c}$ & $11.6 \pm 1.2 \mathrm{a}$ & $1.47 \pm 0.19 b c$ \\
\hline & Glomus mosseae & $73.7 \pm 3.3 \mathrm{a}$ & $18.7 \pm 0.5 \mathrm{bc}$ & $45.5 \pm 5.1 \mathrm{ab}$ & $1.0 \pm 0.05 \mathrm{c}$ & $1.61 \pm 0.08 b$ \\
\hline & Gigaspora gigantea & $28 \pm 2.9 b$ & $20.3 \pm 0.8 \mathrm{ab}$ & $37.1 \pm 3.1 \mathrm{bc}$ & $1.5 \pm 0.09 \mathrm{c}$ & $0.94 \pm 0.25 \mathrm{c}$ \\
\hline & Co-inoculation & $77 \pm 6.6 \mathrm{a}$ & $20.0 \pm 0.5 \mathrm{ab}$ & $53.1 \pm 2.7 \mathrm{a}$ & $3.8 \pm 0.4 \mathrm{~b}$ & $1.24 \pm 0.23 b c$ \\
\hline \multirow[t]{6}{*}{$+\mathrm{Pi}$} & Non-mycorrhizal & 0 & $17.2 \pm 0.9 b$ & $19.8 \pm 2.5 \mathrm{~d}$ & 0 & $0.54 \pm 0.26 \mathrm{~d}$ \\
\hline & Glomus deserticola & $64.9 \pm 7.3 \mathrm{a}$ & $19.3 \pm 1.1 \mathrm{ab}$ & $42.6 \pm 3.2 \mathrm{bc}$ & $0.29 \pm 0.03 c$ & $2.06 \pm 0.1 \mathrm{a}$ \\
\hline & Glomus intraradices & $71.8 \pm 4.6 \mathrm{a}$ & $21.6 \pm 0.6 \mathrm{a}$ & $45.1 \pm 1.3 b c$ & $10.0 \pm 0.1 \mathrm{a}$ & $1.88 \pm 0.08 \mathrm{ab}$ \\
\hline & Glomus mosseae & $72.0 \pm 2.7 \mathrm{a}$ & $20.1 \pm 1.1 \mathrm{a}$ & $51.2 \pm 5.9 \mathrm{ab}$ & $1.1 \pm 0.03 \mathrm{c}$ & $1.74 \pm 0.15 b$ \\
\hline & Gigaspora gigantea & $20.3 \pm 1.4 b$ & $20.7 \pm 0.8 \mathrm{a}$ & $38.0 \pm 5.0 \mathrm{c}$ & $1.2 \pm 0.17 \mathrm{c}$ & $1.31 \pm 0.06 \mathrm{c}$ \\
\hline & Co-inoculation & $76.6 \pm 2.0 \mathrm{a}$ & $20.9 \pm 0.7 a$ & $63.1 \pm 5.7 \mathrm{a}$ & $6.6 \pm 0.4 \mathrm{~b}$ & $1.65 \pm 0.02 b$ \\
\hline \multicolumn{7}{|c|}{ Significance $^{\mathrm{a}}$ due to } \\
\hline \multicolumn{2}{|c|}{ AM inoculation } & $* * *$ & $* * *$ & $* * *$ & $* * *$ & $* * *$ \\
\hline \multicolumn{2}{|c|}{ Pi treatments } & $*$ & $* * *$ & $* * *$ & NS & NS \\
\hline \multicolumn{2}{|c|}{ AM inoculation $\times$ Pi treatment } & $\mathrm{NS}$ & $* * *$ & NS & $* *$ & $* * *$ \\
\hline
\end{tabular}

NS not significant

$* P<0.05 ; * * P<0.01 ; * * * P<0.001$

${ }^{\mathrm{a}}$ By analysis of variance 
influenced shoot dry weight (Table 1). In the absence of Pi, the dry weight of maize shoots colonized by $G$. intraradices was significantly higher than that colonized by $G$. mosseae and $G$. deserticola. There was no significant difference in dry weight among the five AM treatments on the addition of Pi. Nonmycorrhizal plants had significantly lower dry weights than AM inoculated plants under both Pi treatments (Table 1). Overall, Pi addition increased the dry weight of maize (Table 1).

Phosphate uptake was influenced by both AM inoculation $(P<0.0001)$ and Pi treatment $(P<0.001)$ (Table 1$)$. The colonization of roots by AM fungi increased Pi uptake in maize shoots under both Pi treatments compared with nonmycorrhizal controls. Inoculation with a mixture of AM fungi led to the greatest Pi uptake. Pi uptake in plants colonized by G. intraradices or Gigaspora gigantea was lower than that colonized by G. mosseae regardless of Pi treatment. Overall, the addition of Pi increased Pi uptake by maize (Table 1).

\section{Expression of Pi transporter genes}

The relative expression of the AM-inducible Pi transporter gene ZEAma:Pht1;6 was influenced by AM inoculation $(P<0.0001)$, $\mathrm{P}$ treatment $(P<0.0001)$ and their interaction $(P<0.001)$ (Table 2$)$. Colonization of maize roots by AM fungi greatly increased the relative expression of ZEAma:Pht1;6 compared to non-mycorrhizal roots under both $\mathrm{Pi}$ treatments. The expression of ZEAma:Pht1;6 in mycorrhizal roots was 26-135 times higher than that in non-mycorrhizal roots. The different AM inoculations showed varying expression of ZEAma:
Pht 1;6. In the absence of $\mathrm{Pi}$, the relative expression of ZEAma:Pht1;6 was higher in the AM mixture compared to the other four inoculations. The expression was also higher in G. mosseae or G. intraradices compared to $G$. deserticola or Gigaspora gigantea. The addition of $\mathrm{Pi}$ led to high expression of ZEAma:Pht1;6 in roots colonized by the AM mix, and G. mosseae was higher than that of $G$. deserticola and G. intraradices. Overall, the addition of $\mathrm{Pi}$ significantly increased the relative expression of ZEAma:Pht1;6 in plants colonized by AM fungi (Table 2).

Inoculation with $\mathrm{AM}$ fungi significantly decreased the relative expression of the plant root $\mathrm{Pi}$ transporter ZEAma:Pht1;3 (Table 2). The expression of ZEAma: $P h t 1 ; 3$ in non-mycorrhizal roots was five to 44 times higher than that in mycorrhizal roots. The greatest repression occurred in roots colonized by G. mosseae, G. deserticola, and the AM mix. The addition of Pi increased the expression of ZEAma:Pht1;3 in nonmycorrhizal roots; however, the effect was not significant due to high variation (Table 2).

Relationship among AM colonization, AM biomarkers, maize growth parameters, and Pi transporter expression

The degree of AM colonization was positively correlated with the concentration of AM biomarkers, plant growth parameters, and the expression of ZEAma:Pht1;6 but negatively correlated with the expression of ZEAma:Pht1;3 (Table 3). The two AM biomarkers correlated positively with plant dry weight, Pi uptake, and the expression of ZEAma:Pht1;6, but
Table 2 Influence of different $\mathrm{AM}$ and phosphate $(\mathrm{Pi})$ treatments on the relative expression levels of ZEAma:Pht1;6 and ZEAma:Pht1;3 in maize roots
$N S$ not significant

$* P<0.05 ; * * P<0.01 ; * * * P<$

0.001

${ }^{\mathrm{a}} \mathrm{By}$ analysis of variance

\begin{tabular}{llll}
\hline Pi treatment & AM inoculation & $\begin{array}{l}\text { Relative Expression } \\
\text { level of ZEAma:Pht1;6 } \\
\left(\times 10^{-2}\right)\end{array}$ & $\begin{array}{l}\text { Relative Expression } \\
\text { level of ZEAma:Pht1;3 } \\
\left(\times 10^{-2}\right)\end{array}$ \\
\hline$-\mathrm{Pi}$ & Non-mycorrhizal & $0.23 \pm 0.09 \mathrm{e}$ & $2.27 \pm 0.50 \mathrm{a}$ \\
& Glomus deserticola & $5.92 \pm 0.5 \mathrm{~d}$ & $0.14 \pm 0.05 \mathrm{c}$ \\
& Glomus intraradices & $16.3 \pm 1.3 \mathrm{~b}$ & $0.49 \pm 0.21 \mathrm{~b}$ \\
& Glomus mosseae & $12.1 \pm 1.7 \mathrm{bc}$ & $0.04 \pm 0.03 \mathrm{c}$ \\
& Gigaspora gigantea & $8.63 \pm 2.7 \mathrm{~cd}$ & $0.19 \pm 0.04 \mathrm{bc}$ \\
& Co-inoculation & $30.7 \pm 2.9 \mathrm{a}$ & $0.30 \pm 0.14 \mathrm{bc}$ \\
& Non-mycorrhizal & $0.50 \pm 0.06 \mathrm{~d}$ & $3.73 \pm 1.18 \mathrm{a}$ \\
& Glomus deserticola & $15.7 \pm 4.6 \mathrm{c}$ & $0.10 \pm 0.01 \mathrm{~cd}$ \\
& Glomus intraradices & $19.5 \pm 1.8 \mathrm{bc}$ & $0.60 \pm 0.13 \mathrm{~b}$ \\
& Glomus mosseae & $30.1 \pm 2.3 \mathrm{a}$ & $0.08 \pm 0.01 \mathrm{~d}$ \\
Significance due to & Gigaspora gigantea & $24.5 \pm 3.2 \mathrm{ab}$ & $0.20 \pm 0.03 \mathrm{c}$ \\
AM inoculation & & $27.3 \pm 1.3 \mathrm{a}$ & $0.22 \pm 0.09 \mathrm{~cd}$ \\
Pi treatments & & $* * *$ & $* * *$ \\
AM inoculation $\times$ Pi treatment & $* * *$ & $\mathrm{NS}$ \\
\hline
\end{tabular}


Table 3 Pearson correlations among AM colonization, AM fungal fatty acid biomarker concentrations, maize growth, and Pi transporter expression parameters $* P<0.05 ; * * P<$
$* * * P<0.001$

\begin{tabular}{lllllll}
\hline & AM colonization & C16:1cis11 & C18:1cis11 & Pi uptake & $\begin{array}{l}\text { Dry } \\
\text { weight }\end{array}$ & $\begin{array}{l}\text { ZEAma: } \\
\text { Pht } 1 ; 3\end{array}$ \\
\hline C16:1 cis11 & $0.53^{* *}$ & - & - & - & - & - \\
C18:1 cis 11 & $0.53^{* *}$ & 0.04 & - & - & - & - \\
Pi uptake & $0.76^{* * *}$ & 0.30 & $0.39^{*}$ & - & - & - \\
Dry weight & $0.56^{* * *}$ & $0.51^{* *}$ & $0.51^{* *}$ & $0.67^{* * *}$ & - & - \\
ZEAma:Pht $1 ; 3$ & $-0.64^{* * *}$ & 0.20 & $-0.45^{* *}$ & $-0.59^{* * *}$ & $-0.41^{*}$ & - \\
ZEAma:Pht $; 6$ & $0.58^{* * *}$ & $0.36^{*}$ & 0.13 & $0.70^{* * *}$ & $0.53^{* *}$ & $-0.55^{* *}$ \\
\hline
\end{tabular}

negatively with the expression of ZEAma:Pht1;3 (Table 3). The expression of ZEAma:Pht1;6 was positively correlated with plant Pi uptake and dry weight, indicating the importance of this gene to Pi uptake in maize. The expression of ZEAma: $P h t 1 ; 3$ was negatively correlated with plant growth parameters (Table 3).

\section{Discussion}

The present study demonstrated that different AM species show functional diversity in terms of colonization, maize growth, Pi uptake as well as Pi transporter gene expression. The lower degree of colonization found for Gigaspora gigantea reflected different colonization strategies between fungi belonging to Glomaceae and Gigasporaceae (Feddermann et al. 2010). The AM biomarkers varied greatly among the different AM inoculants, and differed from AM colonization data. Variation of AM biomarker data among different AM inoculants has been noted in other studies (Graham et al. 1995; Madan et al. 2002), and apparently, a single fatty acid biomarker is not adequate to represent the biomass of all AM species. Maize colonized by AM fungi showed positive growth response compared to non-mycorrhizal maize, supporting the high AM dependency of maize (Hamel and Smith 1991).

All AM inoculations significantly increased the expression level of the AM-inducible Pi transporter (ZEAma:Pht1;6) and decreased the Pi starvation-inducible Pi transporter (ZEAma: $P h t 1 ; 3)$ in maize roots. The increased expression of ZEAma: Pht1;6 in AM-colonized maize has been found in previous studies (Glassop et al. 2005; Nagy et al. 2006). For the Pi starvation-inducible Pi transporter genes, the expression of ZEAma:Pht1;1, ZEAma:Pht1;4, and ZmPT3 was found to decrease in maize root colonized by $G$. intraradices (Nagy et al. 2006; Wright et al. 2005), while the expression of ZEAma:Pht1;3 remained relatively constant (Nagy et al. 2006). This is inconsistent with our data and may be due to: (1) different methods used in quantifying gene expression level and (2) different maize hybrids. In the study of Nagy et al. (2006), the gene expression level was quantified using RNA gel blot method, which is a qualitative or semiquantitative method (Mirucki 2009). Using real-time RT-
PCR the expression of ZEAma:Pht1;3 was decreased by colonization with $G$. intraradices, but the relative decrease ( $\sim 5$ times vs $\mathrm{CK}$ ) was much lower compared to other AM species ( $\sim 50$ times for G. mosseae). The study of Wright et al. (2005) found that the expression of ZEAma:Pht1;1 and ZEAma:Pht1;4 was decreased in maize root colonized by $G$. intraradices, but the relative decrease differed between the two maize hybrids (River and H511). Thus, different maize hybrids (a local commercial hybrid in our study and Gaspé Flint in the study by Nagy et al. (2006)) may also explain the inconsistency.

AM fungi were found to differ in their ability to induce the expression of ZEAma:Pht1;6. Although G. deserticola, G. intraradices, and $G$. mosseae had similar AM colonization, the expression of ZEAma:Pht1;6 was significantly lower in maize roots colonized by $G$. deserticola than either $G$. intraradices or G. mosseae in the -Pi treatment. In contrast, Gigaspora gigantea had a relatively high expression level of ZEAma:Pht1;6 at a much lower AM colonization. It is believed that the AM-inducible Pi transporters are involved in plant uptake of Pi released by the fungus in the plant root (Smith et al. 2011). A positive correlation between the expression of ZEAma:Pht1;6 and Pi uptake was found in our study and is supported by the work of Grace et al. (2009). In tomato, the expression of AM-inducible Pi transporter genes (LePT3 and LePT4) was positively correlated to the fungal contribution to plant Pi content (Poulsen et al. 2005), consistent with our study. Thus, the variation in expression of AM-inducible Pi transporter genes may reflect differing amounts of Pi released from the intra-radical hyphae by different fungal species. Co-inoculation resulted in the highest expression level of ZEAma:Pht1;6 (especially in the -Pi treatment) as well as the highest Pi uptake, suggesting a high diversity of AM colonization may transfer more Pi to the intra-radical hyphae within maize roots. The present data provide additional support for AM-inducible Pi transporter genes as markers for a functional mycorrhizal Pi uptake pathway in plants (Javot et al. 2007; Poulsen et al. 2005).

The expression of ZEAma:Pht1;3 also varied among AM species, with the greatest reduction in expression on colonization by $G$. mosseae. Burleigh et al. (2002) also found that $G$. mosseae resulted in the greatest reduction in MtPT2 (a Pi 
starvation-inducible gene) in $M$. truncatula. However, the mechanisms by which AM colonization reduces expression of plant Pi starvation-inducible Pi transporters are still unclear. Smith et al. (2011) suggested that the upregulation of Pi transporters in non-mycorrhizal plants may be part of "stress responses," and Burleigh and Bechmann (2002) suggested that factors other than those involving the Pi nutrition of plant may play important roles in influencing gene expression. It has been hypothesized that changes in carbon allocation during the symbiosis may influence expression of plant Pi transporter genes (Burleigh and Bechmann 2002); however, it is not clear whether downregulation of plant $\mathrm{Pi}$ transporters can also be triggered by the plant in response to fungal contact (Javot et al. 2007).

The addition of Pi significantly increased the relative expression of ZEAma:Pht1;6 in AM plants but not that of ZEAma:Pht1;3. This is not surprising given AM fungi would transfer more Pi to the intra-radical hyphae after the addition of Pi. Although, ZEAma:Pht1;3 was reported to be a Pi starvation-inducible gene (Nagy et al. 2006), the Pi concentration used in our study was sufficiently low to have no effect on the expression of ZEAma:Pht1;3.

In conclusion, different AM fungal inoculations display functional diversity in Pi uptake by maize. The colonization of maize by AM fungi significantly decreased the expression level of the Pi starvation-inducible Pi transporter gene ZEAma:Pht1;3, but increased the expression of the AMinducible Pi transporter gene ZEAma:Pht1;6. AM species showed variable effects on expression of the two genes, and increasing the diversity of AM fungi in maize roots through co-inoculation with all four AM species led to higher expression of ZEAma:Pht1;6 as well as Pi uptake in shoots. The expression of ZEAma:Pht1;6 was positively correlated with AM colonization rate, concentration of AM biomarkers, Pi uptake and dry weight of shoot, supporting its use as an indicator of AM function in maize. Addition of low levels of Pi fertilizer significantly increased the expression of ZEAma:Pht1;6.

Acknowledgments The work was funded by the National Natural Science Foundation of China (Program no. 41201239), the Natural Science Basic Research Plan in Shaanxi Province of China (program no. 2012JQ3011), and the University of Nebraska. We thank Elizabeth Jeske for the assistance in the AM biomarker analysis, and Ryan McGhee and Jennifer McGhee for the assistance in the molecular analyses. We also thank Ruth Miller for the assistance in the greenhouse.

\section{References}

Amano N, Shinmen Y, Akimoto K, Kawashima H, Amachi T (1992) Chemotaxonomic significance of the fatty acid composition in the genus Mortierella (Zygomycetes, Mortierellaceae). Mycotaxon 44:257-267
Benedetto A, Magurno F, Bonfante P, Lanfranco L (2005) Expression profiles of a phosphate transporter gene (GmosPT) from the endomycorrhizal fungus Glomus mosseae. Mycorrhiza 15:620-627

Bucher M (2007) Functional biology of plant phosphate uptake at root and mycorrhiza interfaces. New Phytol 173:11-26

Burleigh SH, Bechmann IE (2002) Plant nutrient transporter regulation in arbuscular mycorrhizas. Plant Soil 244:247-251

Burleigh SH, Cavagnaro T, Jakobsen I (2002) Functional diversity of arbuscular mycorrhizas extends to the expression of plant genes involved in P nutrition. J Exp Bot 53:1593-1601

Ding D, Zhang LF, Wang H, Liu ZJ, Zhang ZX, Zheng YL (2009) Differential expression of miRNAs in response to salt stress in maize roots. Ann Bot 103:29-38

Feddermann N, Finlay R, Boller T, Elfstrand M (2010) Functional diversity in arbuscular mycorrhiza - the role of gene expression, phosphorous nutrition and symbiotic efficiency. Fungal Ecol 3:1-8

Genre A, Bonfante P (1998) Acin versus tubulin configuration in arbuscule-containing cells from mycorrhizal tobacco roots. New Phytol 140:745-752

Glassop D, Smith SE, Smith FW (2005) Cereal phosphate transporters associated with the mycorrhizal pathway of phosphate uptake into roots. Planta 222:688-698

Grace EJ, Cotsaftis O, Tester M, Smith FA, Smith SE (2009) Arbuscular mycorrhizal inhibition of growth in barley cannot be attributed to extent of colonization, fungal phosphorus uptake or effects on expression of plant phosphate transporter genes. New Phytol 181:938-949

Graham JH, Hodge NC, Morton JB (1995) Fatty acid methyl ester profiles for characterization of Glomalean fungi and their endomycorrhizae. Appl Environ Microbiol 61:58-64

Grigera MS, Drijber RA, Wienhold BJ (2007a) Increased abundance of arbuscular mycorrhizal fungi in soil coincides with the reproductive stages of maize. Soil Biol Biochem 39:1401-1409

Grigera MS, Drijber RA, Shores-Morrow RH, Wienhold BJ (2007b) Distribution of the arbuscular mycorrhizal biomarker C16:1 cis 11 among neutral, glyco and phospholipids extracted from soil during the reproductive growth of corn. Soil Biol Biochem 39:15891596

Hamel C, Smith DL (1991) Plant development in a mycorrhizal fieldgrown mixture. Soil Biol Biochem 23:661-665

Harrison MJ, Dewbre GR, Liu J (2002) A phosphate transporter from Medicago truncatula involved in the acquisition of phosphate released by arbuscular mycorrhizal fungi. Plant Cell 14:24132429

Javot H, Pumplin N, Harrison MJ (2007) Phosphate in the arbuscular mycorrhizal symbiosis: transport properties and regulatory roles. Plant Cell Environ 30:310-322

Madan R, Pankhurst C, Hawke B, Smith S (2002) Use of fatty acids for identification of AM fungi and estimation of the biomass of AM spores in soil. Soil Biol Biochem 34:125-128

Mirucki CS (2009) The characterization of structure and biologic activity of novel lipids from Porphyromonas endodontalis. Dissertation, University of Connecticut

Nagy F, Karandashov V, Chague W, Kalinkevich K, Tamasloukht M, Xu GH, Jakobsen I, Levy AA, Amrhein N, Bucher M (2005) The characterization of novel mycorrhiza-specific phosphate transporters from Lycopersicon esculentum and Solanum tuberosum uncovers functional redundancy in symbiotic phosphate transport in solanaceous species. Plant J 42:236-250

Nagy R, Vasconcelos MJV, Zhao S, McElver J, Bruce W, Amrhein N, Raghothama KG, Bucher M (2006) Differential regulation of five Pht1 phosphate transporters from Maize (Zea mays L.). Plant Biol 8:186-197

Paszkowski U, Kroken S, Roux C, Briggs SP (2002) Rice phosphate transporters include an evolutionarily divergent gene specifically activated in arbuscular mycorrhizal symbiosis. Proc Natl Acad Sci U S A 99:13324-13329 
Phillips J, Hayman D (1970) Improved procedures for cleaning and staining parasitic and vesicular arbuscular mycorrhizal fungi for rapid assessment of infection. Trans Br Mycol Soc 55:158-160

Poulsen KH, Nagy R, Gao LL, Smith SE, Bucher M, Smith FA, Jakobsen I (2005) Physiological and molecular evidence for Pi uptake via the symbiotic pathway in a reduced mycorrhizal colonization mutant in tomato associated with a compatible fungus. New Phytol 168:445-454

SAS Institute I (1999) SAS/STATs user's guide, Version 8. SAS Institute Inc., Cary

Smith SE, Read DJ (2008) Mycorrhizal symbiosis. Academic Press Ltd., London

Smith SE, Smith FA, Jakobsen I (2003) Mycorrhizal fungi can dominate phosphate supply to plants irrespective of growth responses. Plant Physiol 133:16-20

Smith SE, Jakobsen I, Grønlund M, Smith FA (2011) Roles of arbuscular mycorrhizas in plant phosphorus nutrition: interactions between pathways of phosphorus uptake in arbuscular mycorrhizal roots have important implications for understanding and manipulating plant phosphorus acquisition. Plant Physiol 156:1050-1057

Trouvelot A, Kough J, Gianinazzi-Pearson V (1986) Mesure dutaux de mycorrhization VA d'un systeme radiculaire. Recherche de methods d'estimation ayant une signification fonctionnelle. In: Gianinazzi-Pearson V, Gianinazzi S (eds) Physiological and genetic aspects of mycorrhizae. INRA, Paris

van Aarle IM, Rouhier H, Saito M (2002) Phosphatase activities of arbuscular mycorrhizal intraradical and extraradical mycelium, and their relation to phosphorus availability. Mycol Res 106:1224-1229

Wright DP, Scholes JD, Read DJ, Rolfe SA (2005) European and African maize cultivars differ in their physiological and molecular responses to mycorrhizal infection. New Phytol 167:881-896

Zelles L (1999) Fatty acid patterns of phospholipids and lipopolysaccharides in the characterisation of microbial communities in soil: a review. Biol Fert Soils 29:111-129 